\title{
FAKTOR-FAKTOR KEPUTUSAN PEMBELIAN BUAH LOKAL PADA MASA PANDEMI COVID 19
}

\author{
Resista Vikaliana ${ }^{1 *}$, Antoni Ludfi Arifin ${ }^{2}$, Siti Mariam ${ }^{3}$, Irwansyah ${ }^{4}$, Yusup Rachmat Hidayat ${ }^{5}$ \\ 1,5Program Studi Manajemen Logistik, Institut IImu Sosial dan Manajemen Stiami, Jakarta \\ 2,3 Program Studi Administrasi Bisnis, Institut Ilmu Sosial dan Manajemen Stiami, Jakarta \\ ${ }^{4}$ Program Studi Manajemen, STIE Gasantara, Sukabumi \\ dosenresistaok@gmail.com
}

\begin{abstract}
Abstrak
Penelitian ini bertujuan mengetahui faktor-faktor yang mendorong konsumen memutuskan untuk membeli buah lokal selama masa pandemi Covid 19. Penelitian dilakukan pada masa pandemi Covid 19 tahun 2020 dengan pendekatan kuantitatif. Pengumpulan data dilakukan melalui kuesioner pada 322 sampel, yang kemudian dianalisis dengan analisis faktor Pengumpulan data melalui penyebaran kuesioner terhadap responden penelitian selama masa pandemi Covid 19 pada tahun 2020. Sampel ditarik dengan dengan simple random sampling dari populasi konsumen yang mengonsumsi buah lokal selama tahun 2020, 322 responden bersedia melakukan pengisian kuesioner. Hasil penelitian diolah dengan bantuan software SPSS versi 26 . Hasil penelitian membuktikan hipotesis dengan nilai signifikansi 0,00 bahwa faktor yang diteliti memiliki korelasi untuk dianalisis lebih lanjut. Selain itu, hasil penelitian menunjukkan bahwa dari 10 faktor yang diteliti yaitu keragaman buah lokal, kualitas buah lokal, kebersihan buah lokal, kesegaran buah lokal, harga buah lokal, gaya hidup sehat, tingkat pendapatan, keinginan dan kebutuhan, bentuk buah lokal, dan warna buah lokal kemudian tereduksi menjadi dua variabel yaitu variabel persepsi kualitas dan variabel preferensi konsumen.
\end{abstract}

Kata Kunci: keputusan pembelian. buah lokal, pandemi Covid 19, analisis faktor

\begin{abstract}
This study aims to determine the factors that encourage consumers to decide to buy local fruit during the Covid 19 pandemic. The study was conducted during the Covid 19 pandemic in 2020 with a quantitative approach. Data collection was carried out through a questionnaire on 322 samples, which were then analyzed by factor analysis. The results showed that of the 10 factors studied, namely local fruit diversity, local fruit quality, local fruit cleanliness, local fruit freshness, local fruit prices, healthy lifestyle, income level, wants and needs, local fruit shape, and local fruit color, then reduced to two variables, namely the variable quality perception and consumer preference variables..
\end{abstract}

Keywords: : buying decision. local fruit, Covid 19 pandemic, factor analysis

\section{Pendahuluan}

Pada masa pandemi Covid 19 ini, kesadaran masyarakat terhadap pentingnya menjaga kesehatan meningkat (Saputro et al., 2020). Kesadaran menjaga kesehatan kemudian diikuti dengan memperhatikan konsumsi makanan, salah satunya adalah mengonsumsi buah (Kamelia et al., 2021). Sebagai negara tropis, beraneka ragam buahbuahan ada di Indonesia, yang kemudian disebut dengan buah lokal. Sejak pandemi Covid 19 melanda, pada awal Maret 2020 lalu, komoditi hortikultura khususnya permintaan sayur dan buah lokal segar mengalami peningkatan. Hal ini disebabkan konsumsi buah dan sayur masyarakat meningkat, untuk meningkatkan imunitas (Kamelia et al., 2021; Saputro et al., 2020). Saat ini (2021), buahbuahan yang mengalami lonjakan permintaan di antaranya jambu biji, jeruk lemon dan alpukat. Buah-buahan tersebut banyak diproduksi oleh petani-petani Indonesia. Berdasarkan data BPS (2020), tren produksi buah-buahan lokal pada kurun waktu 4 tahun terakhir terkonfirmasi mengalami peningkatan. Pada tahun 2019 produksi buah-buahan lokal 
mencapai 22,5 juta ton atau naik $4,8 \%$ dibanding tahun 2018.

Perilaku konsumsi masyarakat mengalami perubahan pada pandemi Covid-19 yang mempengaruhi keputusan dalam pembelian komoditi yang dikonsumsinya seperti perilaku mengonsumsi olahan buah lokal dalam bentuk jus / juice (Dzikrayah, 2020; Irianto et al., 2021). Perilaku pembelian buah lokal telah diteliti oleh beberapa peneliti sebelumnya, yang menghasilkan bahwa faktor harga, kandungan zat, kesegaran, warna, manfaat bagi kesehatan dan kemudahan dalam memperoleh buah lokal adalah berpengaruh terhadap keputusan pembelian (Trisna, 2017). Selain itu, persepsi dan preferensi konsumen juga mempengaruhi keputusan pembelian (Sungkawa et al., 2015) serta etnosentrisme (Anggasari et al., 2013).

Adanya perubahan perilaku konsumsi dalam pembelian buah selama masa pandemi, berimplikasi pada pangsa pasar buah lokal. Buah lokal dapat mendominasi pasar buah di Indonesia. $\mathrm{Hal}$ ini dapat memberikan kesempatan atau peluang pasar bagi pemain buah lokal dari hulu sampai hilir atau dari petani hingga pengecer buah lokal. Selain itu, belum pernah dilakukan penelitian tentang keputusan pembelian buah lokal pada masa pandemi Covid 19 sehingga penelitian ini penting untuk dilakukan. Berdasarkan hal tersebut, penelitian ini bertujuan ingin mengetahui faktor-faktor yang mendorong konsumen memutuskan untuk membeli buah lokal selama masa pandemi Covid 19.

\section{Faktor-faktor yang mempengaruhi pembelian}

Kotler menyatakan bahwa perilaku pembelian konsumen dipengaruhi oleh faktorfaktor berikut (Kotler, 2005, 2007) :

- Faktor budaya

Faktor-faktor budaya mempunyai pengaruh yang paling luas dan paling dalam. Budaya, sub-budaya, dan kelas sosial sangat penting bagi perilaku pembelian. Budaya merupakan penentu keinginan dan perilaku yang paling dasar. Sub budaya mencakup kebangsaan, agama, kelompok ras, dan wilayah geografis. Sedangkan kelas sosial adalah pembagian masyarakat yang relatif homogen dan permanen, yang tersusun secara hirarkis dan yang para anggotanya menganut nilai, minat, dan perilaku yang serupa. Kelas sosial tidak hanya mencerminkan penghasilan, tetapi juga indikator lain seperti pekerjaan, pendidikan, dan wilayah tempat tinggal.

- Faktor sosial

Selain faktor budaya, perilaku konsumen dipengaruhi oleh faktor-faktor sosial seperti kelompok acuan, keluarga, serta peran dan status sosial masyarakat.

- Faktor pribadi

Keputusan pembeli juga dipengaruhi oleh karakteristik pribadi. Karakteristik tersebut meliputi usia dan tahap siklus hidup, pekerjaan, keadaan ekonomi, gaya hidup, serta kepribadian dan konsep-diri pembeli.

- Faktor psikologis

Pilihan pembelian seseorang dipengaruhi oleh empat faktor psikologi utama. Faktor-faktor tersebut terdiri dari motivasi, persepsi, pembelajaran, serta keyakinan dan sikap. Kebutuhan akan menjadi motif jika ia didorong hingga mencapai tahap intensitas yang memadai. Motif adalah kebutuhan yang memadai untuk mendorong seseorang bertindak. Persepsi adalah proses yang digunakan oleh individu untuk memilih, mengorganisasi, dan menginterpretasi masukan informasi guna menciptakan gambaran dunia yang memiliki arti. Persepsi dapat sangat beragam antara individu satu dengan yang lain yang mengalami realitas yang sama.

\section{Keputusan Pembelian}

Keputusan pembelian merupakan tahap dalam proses pengambilan keputusan pembeli di mana konsumen benar-benar membeli. Pengambilan keputusan merupakan suatu kegiatan individu yang secara langsung terlibat dalam mendapatkan dan mempergunakan barang yang ditawarkan. Definisi lain keputusan pembelian adalah keputusan pembeli tentang merek mana yang dibeli. Konsumen dapat membentuk niat untuk membeli merek yang paling disukai. Keputusan pembelian merupakan suatu proses pengambilan 
keputusan akan pembelian yang mencakup penentuan apa yang akan dibeli atau tidak melakukan pembelian (Kotler \& Amstrong, 2012). Menurut Kotler (2005), "Keputusan pembelian adalah suatu tahap dimana konsumen telah memiliki pilihan dan siap untuk melakukan pembelian atau pertukaran antara uang dan janji untuk membayar denganhak kepemilikan atau penggunaan suatu barang atau jasa". Kotler (2005) juga menjelaskan yang dimaksud dengan keputusan pembelian adalah suatu proses penyelesaian masalah yang terdiri dari menganalisa atau pengenalan kebutuhan dan keinginan hingga perilaku setelah pembelian (Kotler, 2005).

Menurut Philip Kotler \& Kevin Lane Keller, keputusan pembelian adalah proses integrasi yang digunakan untuk mengombinasikan pengetahuan untuk mengevaluasi dua atau lebih perilaku alternatif dan memilih satu di antaranya. Keputusan konsumen adalah sebuah pendekatan penyelesaian masalah pada kegiatan manusia untuk membeli suatu barang atau jasa dalam memenuhi keinginan dan kebutuhannya (Kotler \& Keller, n.d.). Sedangkan tahap-tahap proses pengambilan keputusan pembelian meliputi lima tahap. Lima tahap tersebut terdiri atas: pengenalan masalah, pencarian informasi, evaluasi alternatif, dan perilaku pasca pembelian (Kotler, 2005).

\section{Buah Lokal}

Banyak jenis buah-buahan tropis dihasilkan di berbagai wilayah Indonesia. Namun, buah-buahan tersebut kebanyakan membanjiri pasar lokal hanya pada saat panen raya, dan beberapa jenis buah menempati pasar dunia (internasional). Jenis buah-buahan tropis yang dipasarkan di pasaran internasional pada saat ini adalah pisang, nanas, mangga,alpukat, rambutan, markisa, sirsak, jambu biji, belimbing, dan manggis (Sunarjono, 2000).

Menurut Zulkarnain (2009), secara botani, buah dapat didefinisikan sebagai ovari matang dari suatu bunga dengan segala isinya serta bagian-bagian yang terkait erat dari bunga tersebut. Oleh karena itu, buah terdiri atas bagian-bagian seperti dinding ovari atau pericarp (yang berdiferensiasi mejadi eksocarp, endocarp, dan mesocarp), biji, jaringan plasenta, partisi, reseptakel, dan sumbu tangkai bunga (Zulkarnain, 2009).

Berdasarkan asal tanaman buahbuahan, maka tanaman dapat dikelompokkan menjadi dua sumber yaitu :

a. Tanaman buah sub-tropik. Tanaman buah sub-tropik umumnya berasal dari daerah antara 230-400 Lintang, contoh : kasemak, pear.

b. Tanaman buah tropik. Tanaman buah tropik berasal dari daerah khatulistiwa sampai 230 Lintang. Contoh: rambutan, durian, manggis, duku, dan sebagainya.

c. Tanaman buah sub-tropik umumnya masih dapat dikembangkan di daerah tropik seperti: daerah pegunungan ( $\geq 1000$ meter di atas permukaan laut), sedangkan tanaman buah tropik lebih sulit dikembangkan di daerah subtropik (Barus \& Syukri, 2008).

\section{Hipotesis Penelitian}

Penelitian ini menguji atribut atau faktor mana yang berkorelasi dengan variabel keputusan pembelian buah lokal pada masa pandemi. Sehingga, hipotesis dirumuskan sebagai berikut:

$\mathrm{H}_{0}=$ Tidak memiliki korelasi dengan keputusan pembelian buah lokal masa pandemi

$\mathrm{H}_{1}=$ Memiliki korelasi dengan keputusan pembelian buah lokal masa pandemi dan sampel memadai untuk dianalisis lebih lanjut. Apabila sig $>(0,05)$ maka $\mathrm{H}_{0}$ diterima, apabila Sig $<(0,05)$ maka $\mathrm{H}_{0}$ ditolak.

\section{Metode Penelitian}

Penelitian dilakukan dengan pendekatan kuantitatif (Santosa, 2018). Pengumpulan data melalui penyebaran kuesioner terhadap responden penelitian selama masa pandemi Covid 19 pada tahun 2020. Sampel ditarik dengan dengan simple random sampling dengan populasi yakni konsumen yang mengonsumsi buah lokal selama tahun 2020, 322 responden bersedia melakukan pengisian kuesioner.

Analisis faktor digunakan untuk menganalisis data yang terkumpul. Analisis faktor digunakan untuk mereduksi data, yaitu proses untuk meringkas sejumlah variabel menjadi lebih sedikit dan menamakannya sebagai faktor (Lupiyoadi \& Ikhsan, 2015). 
SPSS versi 26 digunakan sebagai software alat bantu pengolahan data penelitian (Vikaliana \& Irwansyah, 2019).

Dalam analisis faktor ini digunakan Uji Barlett. Uji Barlett adalah untuk menguji korelasi antar variabel karena hasil yang diinginkan dalam analisis faktor adalah adanya korelasi yang tinggi antar variabel, memiliki korelasi yang tinggi jika nilai Barlett hitung > Barlett tabel, atau p-value (sig) < $(0,05)$, maka menunjukkan nilai korelasi yang tinggi antar variabel dan proses dapat dilanjutkan. Hipotesis untuk signifikansi adalah :

$\mathrm{H}_{0}=$ Tidak memiliki korelasi

$\mathrm{H}_{1}=$ Memiliki korelasi dan sampel memadai untuk dianalisis lebih lanjut.

Kriteria untuk melihat signifikansi adalah :

Nilai Sig > $(0,05)$ maka $\mathrm{H}_{0}$ diterima , Sig < $(0,05)$ maka $\mathrm{H}_{0}$ ditolak.
Pada penelitian ini, faktor yang diteliti adalah:

1. Keragaman buah lokal

2. Kualitas buah lokal

3. Kebersihan buah lokal

4. Kesegaran buah lokal

5. Harga buah lokal

6. Gaya hidup sehat

7. Tingkat pendapatan

8. Keinginan dan kebutuhan

9. Bentuk buah lokal

10. Warna buah lokal

Faktor yang diteliti tersebut ditelaah dari faktor sosial, pribadi dan psikologis (Kotler, 2005, 2007) serta penelitian terdahulu (Rochaeni, 2013; Sumarwan \& Palupi, 2017; Tarigan et al., 2014). Kerangka penelitian digambarkan pada Gambar 1 di bawah ini

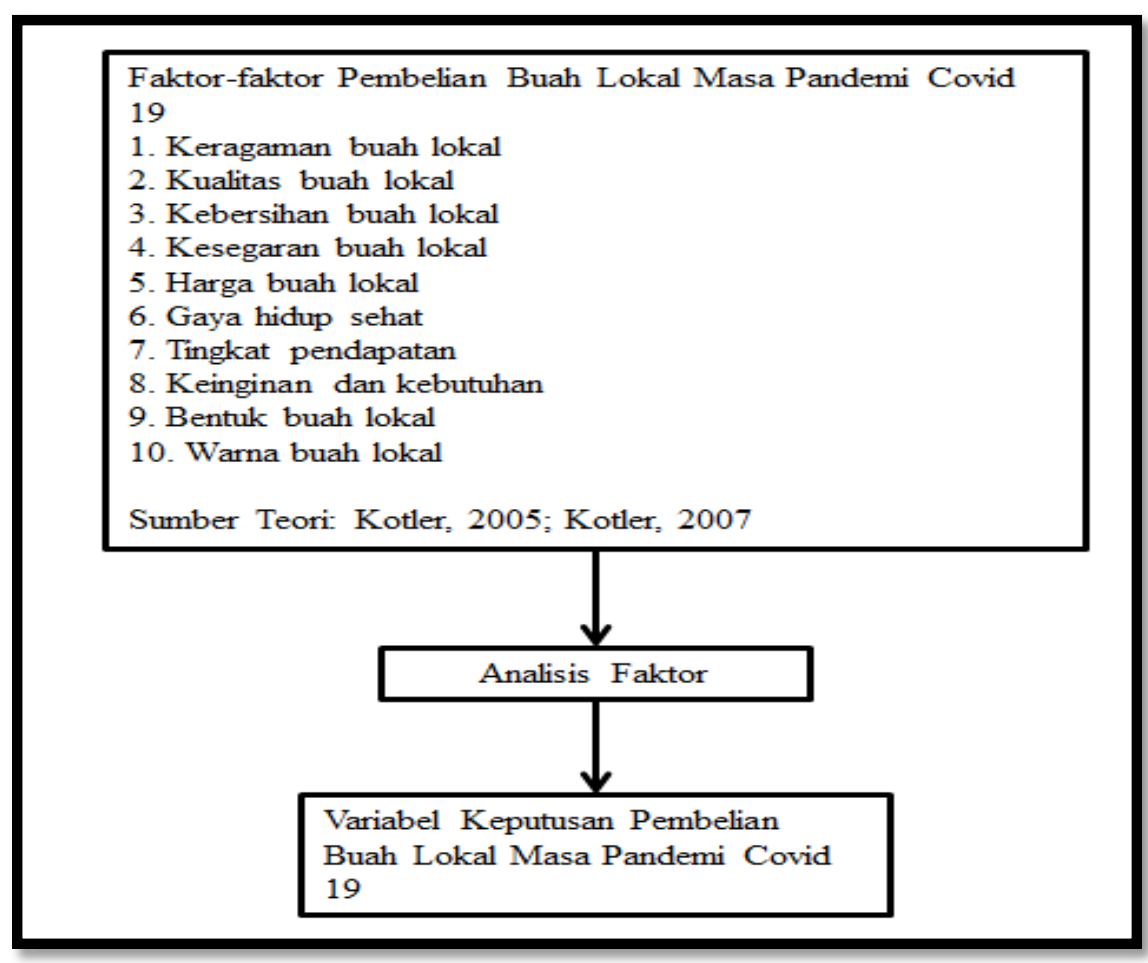

Gambar 1 Kerangka Penelitian

\section{Hasil dan Pembahasan}

Berikut ini merupakan gambaran 322 responden pada penelitian ini. Berdasarkan jenis kelamin, 55,2 adalah perempuan, sedangkan sisanya 44,8 adalah laki-laki (Gambar 2). 

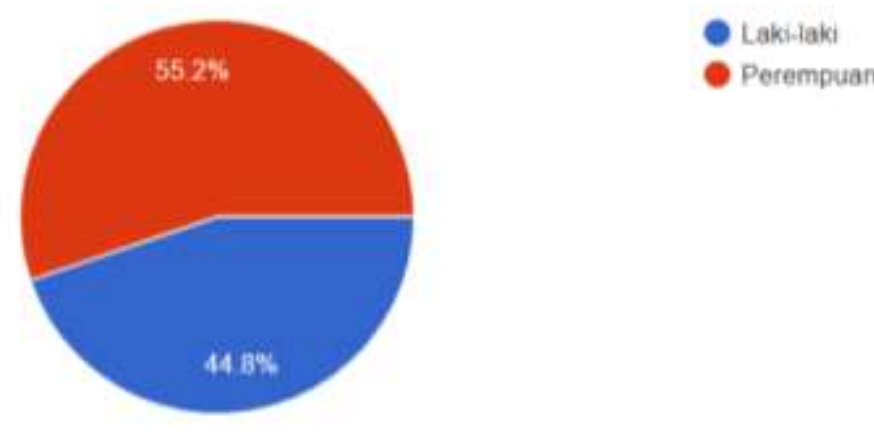

Gambar 2

Gambaran Responden Berdasarkan Jenis Kelamin

Berdasarkan tingkat pendikan, pada Gambar 3 berikut ini, merupakan gambaran responden pada penelitian ini. Responden yang berpendidikan S2 adalah 41,2\%, berpendidikan SMA/ SMU atau SMK adalah 31\%, berpendidikan S1 adalah $16,7 \%$ dan berpendidikan S3 adalah 8,7\%. Sisanya yakni $2,4 \%$, tersebar pada tingkat pendidikan vokasi/ diploma, D3 serta kuliah semester 4.
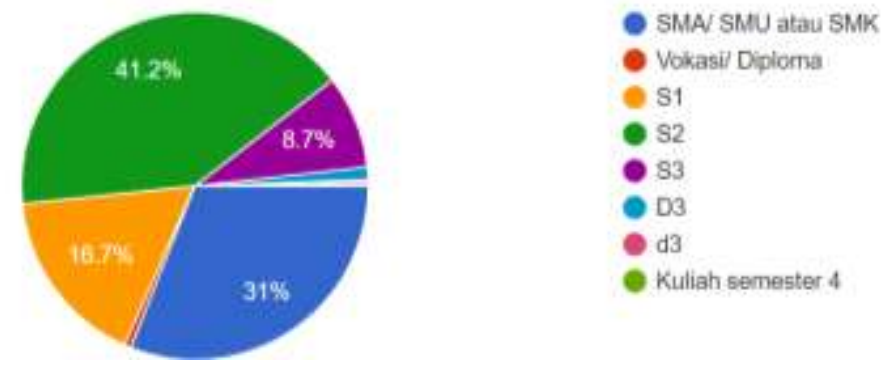

Gambar 3 Gambaran Responden Berdasarkan Tingkat Pendidikan

Sedangkan berdasarkan tingkat memiliki pendapatan $\mathrm{Rp} 3.000 .000,00-\mathrm{Rp}$ pendapatan, seperti terlihat pada Gambar 4 berikut, responden yang mendominasi yakni $40,6 \%$ adalah yang memiliki tingkat pendapatan lebih dari Rp 9.000.000,00. Kemudian $19,4 \%$ adalah responden yang memiliki pendapatan Rp 5.000.000,00-Rp $7.000 .000,00,17,9 \%$ adalah responden yang $5.000 .000,00$ dan $11,3 \%$ adalah responden yang memilik pendapatan Rp 7.000.000,00-Rp $9.000 .000,00$. Sisanya yakni $10,8 \%$, merupakan responden dengan tingkat pendapatan yang tersebar antara Rp 1.000.000,00-Rp 3.000.000,00 dan kurang dari Rp 1.000.000,00.

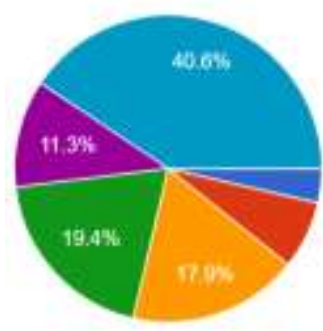

Gambar 4

Gambaran Responden Berdasarkan Tingkat Pendapatan

Pada Tabel 1 berikut diperoleh nilai tingkat signifikan 0,00. Nilai MSA $>0,5$ dan Kaiser-Meyer-OlkinMSA sebesar 0,844 dengan Sig<0,05. Hipotesis untuk signifikansi adalah: 
Jurnal Ekonomi : Journal of Economic p-ISSN 2087-8133| e-ISSN : 2528-326X

$\mathrm{H}_{0}=$ Tidak memiliki korelasi dengan keputusan pembelian buah lokal masa pandemi $\mathrm{H}_{1}=$ Memiliki korelasi dengan keputusan pembelian buah lokal masa pandemi dan sampel memadai untuk dianalisis lebih lanjut. Apabila sig $>(0,05)$ maka $\mathrm{H}_{0}$ diterima, apabila Sig < $(0,05)$ maka $\mathrm{H}_{0}$ ditolak. Pada Tabel 1 nilai signifikan 0,00 atau sig < 0,05, maka $\mathrm{H}_{0}$ ditolak atau $\mathrm{H}_{1}$ diterima. Artinya, atribut atau faktor yang diteliti memiliki korelasi dengan keputusan pembelian buah lokal masa pandemi dan sampel yang memadai untuk dianalisis lebih lanjut.

Tabel 1

KMO and Bartlett's Test

\section{KMO and Bartlett's Test}

\begin{tabular}{llr}
\hline Kaiser-Meyer-Olkin Measure of &, 844 \\
Sampling Adequacy. & \\
\hline Bartlett's Test of & Approx. Chi- & 1193,748 \\
Sphericity & Square & \\
\cline { 2 - 3 } & Df &, 000 \\
\cline { 2 - 3 } & Sig. & \\
\hline
\end{tabular}

Tabel 2 berikut adalah Tabel Anti Image. Pada tabel ini, apabila ada nilai anti image correlation yang ditunjukkan pada garis diagonal dengan simbol a yang nilainya $<0,5$ berarti atribut tersebut dikeluarkan dan dilakukan pengujian ulang.

Tabel 2

Anti-Image Matrices

\begin{tabular}{|c|c|c|c|c|c|c|c|c|c|c|c|}
\hline \multicolumn{12}{|c|}{ Anti-image Matrices } \\
\hline & & $\mathrm{A} 1$ & $\mathrm{~A} 2$ & A3 & A4 & A5 & A6 & A7 & A8 & A9 & $\mathrm{A} 10$ \\
\hline \multirow{20}{*}{$\begin{array}{l}\text { Anti-image } \\
\text { Covariance }\end{array}$} & $\mathrm{A} 1$ & ,587 & - & & 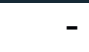 & ,001 & - & - & - & & \\
\hline & & & 103 &, 041 & ,093 & & ,040 & ,016 & ,005 & , 015 & ,041 \\
\hline & $A 2$ & - & 462 & & & - & ,003 & & & - & ,036 \\
\hline & & 103 & & , 168 & ,098 &, 055 & & ,019 &, 040 &, 043 & \\
\hline & A3 & & - & ,422 & & - & - & - & & - & \\
\hline & & ,041 & 168 & & 117 & ,016 & ,095 & ,010 & ,019 & ,023 & ,004 \\
\hline & A4 & - & - & - & ,545 & - & - & ,061 & & ,048 & - \\
\hline & & ,093 & ,098 & 117 & & ,092 & ,043 & & ,089 & & ,039 \\
\hline & A5 & ,001 & - & - & - & ,772 & - & - & - & 005 & - \\
\hline & & & ,055 & ,016 & ,092 & & ,061 & ,156 & 007, & & 001, \\
\hline & A6 & & ,003 & - & - & - & 546, & - & - & 005 & - \\
\hline & & 040, & & 095, & 043, & ,061 & & 019, & 218, & & 038, \\
\hline & A7 & & - & & 061 & - & - & 671 & - & - & - \\
\hline & & ,016, & 019, & ,010, & & 156, & 019, & & 072, & 058, & 029, \\
\hline & A8 & - & - & - & - & - & - & - & 659 & - & 050 \\
\hline & & 005, & ,040 & 019, & 089, & 007, & 218 & 072, & & 023 & \\
\hline & A9 & & - & & 048, & 005, & 005, & - & & 202 & \\
\hline & & 015, & ,043 & ,023, & & & & ,058 & 023, & & 166, \\
\hline & $\mathrm{A} 10$ & & ,036 & & - & - & - & - & 050, & & 210, \\
\hline & & ,041 & & 004, & 039, & ,001 & ,038 & ,029 & & , 166 & \\
\hline \multirow{10}{*}{$\begin{array}{l}\text { Anti-image } \\
\text { Correlation }\end{array}$} & A1 & ,946 & & & & 001, & & & & & \\
\hline & & & 197, & ,082, & 165, & & 071, & ,025 & 009, & 045, & 116, \\
\hline & $\mathrm{A} 2$ & & 875 & & - & - & ,006, & - & - & - & 116, \\
\hline & & 197, & & ,380 & 194 & ,093 & & ,034 & 072 & 142 & \\
\hline & A3 & & & ,891 & & - & - & & & & \\
\hline & & 082 & 380, & & 243, & 028, & 197, & 018, & 035, & 077, & 014, \\
\hline & A4 & & & & 874 & - & & 101 & & 146 & \\
\hline & & 165, & 194, & 243, & & 141 & 078, & & 148, & & 115, \\
\hline & A5 & 001 & & & & ,909 & & & & 013 & \\
\hline & & & 093, & 028, & 141 & & 094, & 217, & 010 & & ,004 \\
\hline
\end{tabular}


Jurnal Ekonomi : Journal of Economic

p-ISSN 2087-8133| e-ISSN : 2528-326X

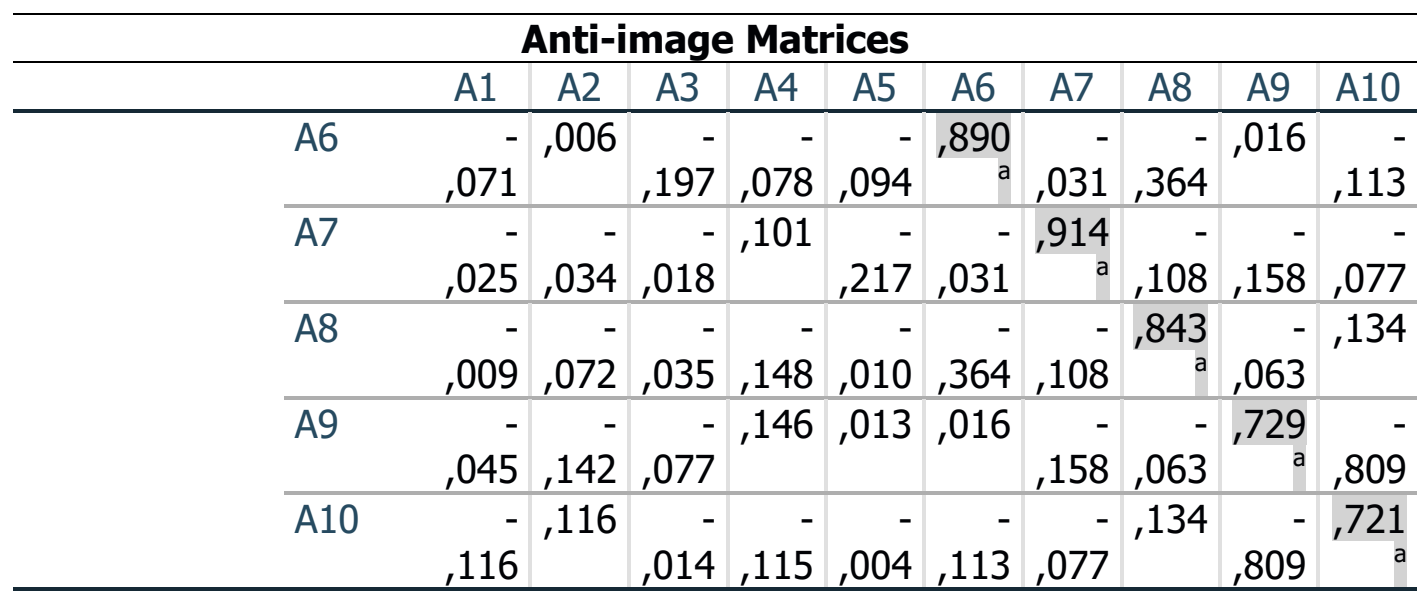

a. Measures of Sampling Adequacy(MSA)

Pada Tabel 2 Anti Image terlihat bahwa nilai anti image correlation pada garis diagonal (diberi warna abu-abu) memiliki tanda a dengan nilai lebih dari 0,5 . Sehingga, tidak ada yang dikeluarkan dan tidak dilakukan pengujian ulang. Tabel 3 Total Variance Explained menjelaskan terbentuknya atribut ke dalam beberapa faktor. Dari 10 atribut yang

dimasukkan, sudah terbentuk 2 faktor yang nantinya akan ditentukan berdasarkan atribut. Dengan kata lain, hanya 2 faktor yang paling baik dalam meringkas 10 atribut. Terbentuknya 2 faktor didasari oleh nilai Eigenvalues $>1$. Selain itu, juga dapat dilihat dari grafik Scree Plot.

Tabel 3

Total Variance Explained

\section{Total Variance Explained}

\begin{tabular}{|c|c|c|c|c|c|c|c|c|c|}
\hline \multirow[b]{2}{*}{$\begin{array}{l}\text { Compone } \\
\text { nt }\end{array}$} & \multicolumn{3}{|c|}{ Initial Eigenvalues } & \multicolumn{3}{|c|}{$\begin{array}{c}\text { Extraction Sums of Squared } \\
\text { Loadings }\end{array}$} & \multicolumn{3}{|c|}{$\begin{array}{l}\text { Rotation Sums of } \\
\text { Squared Loadings }\end{array}$} \\
\hline & Total & $\begin{array}{c}\% \text { of } \\
\text { Variance }\end{array}$ & $\begin{array}{c}\text { Cumulativ } \\
\text { e \% }\end{array}$ & Total & $\begin{array}{c}\% \text { of } \\
\text { Variance }\end{array}$ & $\begin{array}{c}\text { Cumulati } \\
\text { ve } \%\end{array}$ & $\begin{array}{c}\text { Tota } \\
\mathrm{I}\end{array}$ & $\begin{array}{c}\% \text { of } \\
\text { Varian } \\
\text { ce }\end{array}$ & $\begin{array}{c}\text { Cumulativ } \\
\text { e \% }\end{array}$ \\
\hline 1 & 4,622 & 46,221 & 46,221 & 4,622 & 46,221 & 46,221 & $\begin{array}{r}3,35 \\
4\end{array}$ & 33,536 & 33,536 \\
\hline 2 & 1,371 & 13,708 & 59,929 & 1,371 & 13,708 & 59,929 & $\begin{array}{r}2,63 \\
9\end{array}$ & 26,393 & 59,929 \\
\hline 3 & 871 & 8,708 & 68,637 & & & & & & \\
\hline 4 & ,784 & 7,840 & 76,477 & & & & & & \\
\hline 5 &, 554 & 5,541 & 82,018 & & & & & & \\
\hline 6 & ,505 & 5,051 & 87,069 & & & & & & \\
\hline 7 &, 446 & 4,457 & 91,526 & & & & & & \\
\hline 8 &, 430 & 4,295 & 95,821 & & & & & & \\
\hline 9 & ,306 & 3,059 & 98,881 & & & & & & \\
\hline 10 &, 112 & 1,119 & 100,000 & & & & & & \\
\hline
\end{tabular}

Extraction Method: Principal Component Analysis.

Grafik Scree Plot (Gambar 1) memperlihatkan bahwa slope (kemiringan) komponen 1 ke 2 sangat menurun tajam, sedangkan pada slope komponen 3 dan seterusnya juga masih menurun dan berada di bawah nilai 1 pada garis Eigenvalue. Artinya, hanya ada 2 faktor yang dapat diringkas dari 10 atribut. 


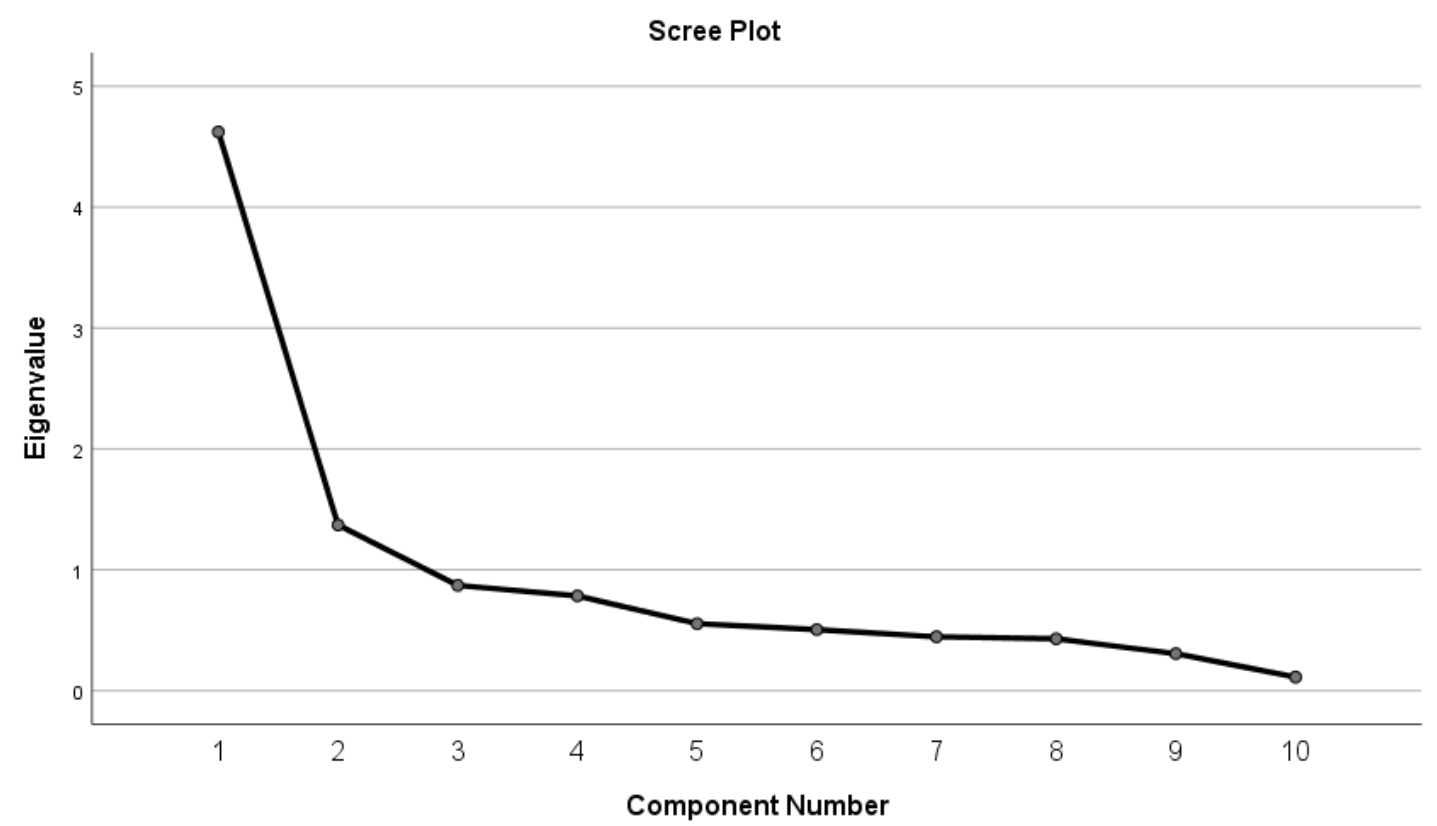

Gambar Grafik Scree Plot

Setelah terbentuk 2 faktor yang paling baik dari 10 atribut, selanjutnya Tabel Component Matrix akan menjelaskan distribusi ke 10 atribut tersebut ke dalam 2 faktor. Artinya, atribut-atribut mana yang akan masuk ke dalam 2 komponen terbentuk. Berdasarkan Tabel 4 Component Matrix terlihat bahwa atribut atau faktor pada komponen/faktor menunjukkan tidak semua korelasi yang dapat dibedakan secara jelas antar komponen. Sebagai contoh, atribut atau faktor 8, komponen 1 yaitu 0,561 dan komponen 2 0,413 . Untuk itu dibutuhkan rotasi agar terjadi hubungan yang semakin jelas.

Tabel 4

Component Matrix

\begin{tabular}{ll|r}
\hline \multicolumn{3}{c}{$\begin{array}{r}\text { Component Matrix } \\
\text { Component }\end{array}$} \\
& 1 & 2 \\
\hline A1 &, 712 &,- 003 \\
\hline A2 &, 753 &, 240 \\
\hline A3 &, 792 &, 213 \\
\hline A4 &, 669 &, 435 \\
\hline A5 &, 527 &, 121 \\
\hline A6 &, 713 &, 204 \\
\hline A7 &, 577 &,- 405 \\
\hline A8 &, 561 &, 413 \\
\hline A9 &, 729 &,- 583 \\
\hline A10 &, 713 &,- 590 \\
\hline
\end{tabular}

Component Matrix
Component
Extraction Method:
Principal Component
Analysis.

a. 2 components extracted.

Hasil rotasi pada komponen matriks memperlihatkan hubungan yang semakin jelas antar faktor. Sebagai contoh atribut A8 atau faktor 8 , pada komponen 2 yang awalnya memiliki hubungan 0,413 , setelah dirotasi nilai korelasinya semakin kecil, yaitu menjadi 0, 028.

Tabel 5

\begin{tabular}{|c|c|c|}
\hline \multicolumn{3}{|c|}{$\begin{array}{c}\text { Rotated Component Matrix } \\
\text { Rotated Component } \\
\text { Matrix }^{\mathrm{a}}\end{array}$} \\
\hline & \multicolumn{2}{|c|}{ Component } \\
\hline & 1 & 2 \\
\hline$\overline{\mathrm{A} 1}$ &, 554 &, 447 \\
\hline $\mathrm{A} 2$ & ,738 & ,282 \\
\hline A3 & ,752 & ,329 \\
\hline A4 & ,794 &, 078 \\
\hline A5 &, 487 & ,235 \\
\hline $\mathrm{A} 6$ & 684 & ,286 \\
\hline A7 & 198 & ,677 \\
\hline A8 & ,696 &, 028 \\
\hline A9 & ,206 & ,910 \\
\hline A10 & 188 & ,906 \\
\hline
\end{tabular}


Jurnal Ekonomi : Journal of Economic

p-ISSN 2087-8133| e-ISSN : 2528-326X

Tabel 6

Component Transformation Matrix

Setelah dapat membedakan korelasi antar-atribut, maka tahapan selanjutnya adalah mengidentifikasi atribut-atribut mana yang masuk ke dalam faktor terbentuk.

Atribut A1 masuk pada faktor ke 1 karena nilai korelasinya paling besar, yaitu 0,554

Atribut A2 masuk pada faktor ke 1 karena nilai korelasinya paling besar, yaitu 0,738

Atribut A3 masuk pada faktor ke 1 karena nilai korelasinya paling besar, yaitu 0,752

Atribut A4 masuk pada faktor ke 1 karena nilai korelasinya paling besar, yaitu 0,794

Atribut A5 masuk pada faktor ke 1 karena nilai korelasinya paling besar, yaitu 0,487

Atribut $A 6$ masuk pada faktor ke 1 karena nilai korelasinya paling besar, yaitu 0,684

Atribut A7 masuk pada faktor ke 2 karena nilai korelasinya paling besar, yaitu 0,677

Atribut A8 masuk pada faktor ke 1 karena nilai korelasinya paling besar, yaitu 0,696

Atribut A9 masuk pada faktor ke 2 karena nilai korelasinya paling besar, yaitu 0,910

Atribut A10 masuk pada faktor ke 2 karena nilai korelasinya paling besar, yaitu 0,906

Setelah 10 atribut terdistribusi ke dalam 2 faktor, maka didefinisikan masing-masing atribut ke dalam 2 variabel baru, yaitu:

1) Faktor $A 1-A 6$ dan $A 8$, keragaman buah lokal (A1), kualitas buah lokal (A2), kebersihan buah lokal (A3), kesegaran buah lokal (A4), harga buah lokal (A5), gaya hidup sehat $(A 6)$, serta keinginan dan kebutuhan (A8), didefinisikan sebagai variabel Persepsi Kualitas

2) Faktor 7, 9, 10, yaitu tingkat pendapatan (A7), bentuk buah lokal (A9) dan warna buah lokal (A10) didefinisikan sebagai variabel Preferensi Konsumen

Untuk membuktikan apakah benar bahwa A1-A10 terbentuk menjadi 2 variabel, maka dapat dilihat pada Tabel Component Transformation Matrix sebagai berikut. 
agar dapat berfokus pada kualitas dan mempertimbangkan preferensi konsumen.

\section{Kesimpulan}

Hasil penelitian menunjukkan bahwa dari 10 faktor yang diteliti yaitu keragaman buah lokal (A1), kualitas buah lokal (A2), kebersihan buah lokal (A3), kesegaran buah lokal (A4), harga buah lokal (A5), gaya hidup sehat (A6), serta keinginan dan kebutuhan (A8), didefinisikan sebagai variabel Persepsi Kualitas. Sedangkan tingkat pendapatan (A7), bentuk buah lokal (A9) dan warna buah lokal (A10) didefinisikan sebagai variabel Preferensi Konsumen. Jadi dari 10 faktor tersebut tereduksi menjadi dua variabel yaitu variabel persepsi kualitas dan variabel preferensi konsumen. Berdasarkan hasil penelitian ini diharapkan dapat memberikan informasi kepada para pelaku industri buah lokal mengenai faktor-faktor pendorong keputusan pembelian buah lokal masa pandemi di Indonesia. Selain itu, hasil penelitian yaitu variabel persepsi kualitas dan preferensi konsumen dapat direkomendasikan untuk penelitian selanjutnya mengenai keputusan pembelian buah lokal di Indonesia. Penelitian ini memiliki keterbatasan pada proporsi responden atau sampel. Sampel tidak ditarik berdasarkan karakteristik khusus atau segmentasi tertentu, misal umur tertentu, sebaran domisili tempat tinggal, tingkat pendapatan dan lainnya, yang merupakan karakteristik yang dapat diteliti sebagai perilaku konsumen secara spesifik.

\section{Daftar Pustaka}

Anggasari, P., Yuliati, L. N., \& Retnaningsih. (2013). Pengaruh Ethnosentrisme terhadap Sikap, Preferensi, dan Perilaku Pembelian Buah Lokal dan Impor. Jurnal Manajemen Dan Agribisnis, 10(2), 128136.

Barus, A., \& Syukri. (2008). Agroteknologi Tanaman Buah-buahan. USU Press.

Dzikrayah, F. (2020). Perilaku Konsumen Muslim terhadap Konsumsi Food and Beverage pada Masa Pandemi Covid-19. Al Muamalat: Jurnal Hukum Ekonomi Syariah, ス1).

Irianto, Fitriarni, D., \& Arahman, E. (2021). Analisa Perilaku Konsumen Dalam
Pengambilan Keputusan Pembelian Jajanan Pasar Pada Masa Pandemi Covid-19 Di Kecamatan Delta Pawan Kabupaten Ketapang. Journal of Food System and Agribusiness, 5(1), 19-27.

Istoto, S., \& Subagja, I. K. (2018). Pengaruh Kualitas Produk dan Promosi terhadap Keputusan Pembelian Buah Melon PT. Syafina Niaga. 6(2).

Kamelia, M., Supriyadi, \& Afif, D. N. Y. (2021). Gambaran Konsumsi Makanan Olahan Masyarakat pada Masa Pandemi Covid19. PROSIDING PENELITIAN DAN PENGABDIAN 2021.

Kotler, P. (2005). Manajemen Pemasaran (Edisi $11 \mathrm{~J})$. PT Indeks.

Kotler, P. (2007). Manajemen Pemasaran (Edisi 12). PT Indeks.

Kotler, P., \& Amstrong, G. (2012). Principle of Marketing. Prentice Hall.

Kotler, P., \& Keller, K. L. (n.d.). Marketing Management.

Lupiyoadi, R., \& Ikhsan, R. B. (2015). Praktikum Metode Riset Bisnis. Salemba Empat.

Rochaeni, S. (2013). Analisis persepsi, kesadaran, dan preferensi konsumen terhadap buah lokal. Agribisns, 71 ).

Santosa, P. I. (2018). Metode Penelitian Kuantitatif (Pengembangan Hipotesis dan Pengujiannya Menggunakan SmartPLS). Penerbit Andi.

Saputro, A. A., Saputra, Y. D., \& Prasetyo, G. B. (2020). Analisis Dampak Covid-19 terhadap Kesadaran Masyarakat dalam Penerapan Protokol Kesehatan. Journal Pendidikan Jasmani Kesehatan Dan Rekreasi (PORKES), 3(2), 81-92.

Simbolon, N. S. D. K., Zargustin, D., \& Nizar, R. (2018). Hubungan persepsi konsumen dengan perilaku mengkonsumsi buah lokal di pasar tradisional arengka kecamatan tampan kota pekanbaru. Agribisnis, 20(1), 75-85.

Sumarwan, U., \& Palupi, E. (2017). Preferensi konsumen terhadap buah-buahan lokal dan organik serta implikasinya terhadap pendidikan konsumen cinta produk nasional. Jurnal IImu Keluarga Dan Konsumen, 10(2), 157-168.

Sunarjono, H. H. (2000). Prospek Berkebun Buah. Penebar Swadaya. 
Sungkawa, I., Purnomo, D., \& Fauziah, E. (2015). Hubungan Antara Persepsi dan Preferensi Konsumen dengan Pengambilan Keputusan Pembelian Buah Lokal (Studi Kasus di Pasar Harjamukti, Pasar Pagi, dan Pasar Kanoman Kota Cirebon). Agrijati, 28(1), 79-99.

Tarigan, A. R., Hadi, S., \& Sayamar, E. (2014). Analisis Perilaku Konsumen dalam Pembelian Buah Lokal di Pasar Tradisional Arengka Kota Pekanbaru. Jurnal Online Mahasiswa Fakultas Pertanian, 1(1), 1-14.

Trisna, D. (2017). Analisis Perilaku Konsumen terhadap Pembelian Produk Buah Lokal di Pasar Modern Kota Palopo. PERBAL: Jurnal Pertanian Berkelanjutan, 5(2).

Vikaliana, R., \& Irwansyah. (2019). Pengolahan Data dengan SPSS. CV AA RIZKY. https://ideas.repec.org/p/osf/thesis/zhy m7.html

Yuliawati, Marina, I., \& Sumantri, K. (2020). Analisis Preferensi Konsumen terhadap Keputusan Pembelian Buah Mangga( Mangifera indica L ). Agrivet: Jurnal IImu-IImu Pertanian Dan Peternakan, 8(1), 44-50.

Zulkarnain. (2009). Dasar-dasar Hortikultura. Bumi Aksara. 